\title{
Content of short-chain fatty acids in the hindgut of rats fed processed bean (Phaseolus vulgaris) flours varying in distribution and content of indigestible carbohydrates
}

\author{
Åsa M. Henningsson*, E. Margareta G. L. Nyman and Inger M. E. Björck \\ Applied Nutrition and Food Chemistry, Center for Chemistry and Chemical Engineering, Lund University, \\ PO Box 124, SE-221 00 Lund, Sweden
}

(Received 3 July 2000 - Revised 2 May 2001 - Accepted 10 May 2001)

\begin{abstract}
Red kidney beans (Phaseolus vulgaris) processed to differ in distribution and content of indigestible carbohydrates were used to study hindgut fermentability and production of shortchain fatty acids (SCFA). Bean flours with low or high content of resistant starch (RS), mainly raw and physically-inaccessible starch, were obtained by milling the beans before or after boiling. Flours containing retrograded starch and with a high or low content of oligosaccharides were prepared by autoclaving followed by freeze-drying with or without the boiling water. Six diets were prepared from these flours yielding a total concentration of indigestible carbohydrates of 90 or $120 \mathrm{~g} / \mathrm{kg}$ (dry weight basis). The total fermentability of the indigestible carbohydrates was high with all diets (80-87\%). Raw and physically-inaccessible starch was more readily fermented than retrograded starch $(97-99 \% v .86-95 \% ; P<0 \cdot 05)$. Non-starch glucans were fermented to a lesser extent than RS, but the fermentability was higher $(P<0.05)$ in the case of autoclaved $(50-54 \%)$ than boiled beans $(37-41 \%)$. The distribution between acetic, propionic and butyric acid in the caecum was similar for all diets, with a comparatively high percentage of butyric acid (approximately 18). However, with diets containing the high amounts of RS, the butyric acid concentration was significantly higher in the distal colon than in the proximal colon $(P=0.009$ and $P=0.047$ for the high- and low-level diets respectively), whereas it remained constant, or decreased along the colon in the case of the other diets. Furthermore, the two diets richest in RS also promoted the highest percentages of butyric acid in the distal colon (24 and 17 v. 12 and 12-16 for the high- and low-level diets respectively).
\end{abstract}

Short-chain fatty acids: Red kidney beans: Indigestible carbohydrates

Short-chain fatty acids (SCFA; acetic, propionic and butyric acid) formed during bacterial fermentation of carbohydrates in the colon, have been suggested to have specific physiological effects. Thus, butyric acid, the main energy substrate for the colonocytes (Roediger, 1982), may play a role in the prevention and treatment of various colonic diseases (McIntyre et al. 1993; Hague et al. 1995). In colonic tumour cell lines, butyrate has been shown to inhibit growth (Whitehead et al. 1986), differentiation (Siavoshian et al. 2000) and to induce apoptosis (Hague \& Paraskeva, 1995). Further, patients with distal ulcerative colitis given rectal infusions with SCFA mixtures (Breuer et al. 1991; Vernia et al. 1995) or butyrate alone (Scheppach et al. 1992) improved, regarding symptoms and/or, histological and endoscopic scores. However, lower concentrations of SCFA or butyrate enemas had no effect on diversion colitis
(Guillemot et al. 1991) or distal ulcerative colitis (Steinhart et al. 1996). Propionic acid is discussed as beneficial in relation to lipid metabolism (Venter et al. 1990; Wright et al. 1990; Todesco et al. 1991). It has thus been proposed that propionate may lower plasma cholesterol concentrations by inhibiting hepatic cholesterogenesis (Chen et al. 1984). However, the results from studies examining the effects of propionic acid on cholesterol metabolism are not consistent. Both lack of cholesterol lowering (Bach Knudsen \& Canibe, 1993) and increased plasma cholesterol levels (Beaulieu \& McBurney, 1992) have been observed in pigs caecally infused with propionate. In human subjects however, the synthesis of cholesterol from acetate decreased when propionate was infused rectally (Wolever et al. 1991).

Although not all studies are indicative of colonic or metabolic benefits, the possible health-promoting effect of

Abbreviations: DCF, damaged-cell flour; dwb, dry weight basis; HOF, high-oligosaccharide flour; ICF, intact-cell flour; LOF, low-oligosaccharide flour; NDO, non-digestible oligosaccharides; RS, resistant starch; SCFA, short-chain fatty acids.

* Corresponding author: Åsa Henningsson, fax + 464622245 32, email Asa.Henningsson@inl.lth.se 
SCFA has generated interest in the pattern formed from different carbohydrate sources. The content and distribution of SCFA are dependent on the microflora in the intestinal tract (Macfarlane \& Cummings, 1995) and the carbohydrate substrate (Cummings \& Englyst, 1987; Brighenti et al. 1989). Indigestible carbohydrates reaching the colon are mainly resistant starch (RS), NSP and nondigestible oligosaccharides (NDO). Studies in vivo in pigs (Brown et al. 1997; Martin et al. 1998; Bird et al. 2000) and human subjects (Phillips et al. 1995) have shown that RS yields different proportions of butyrate on fermentation, depending on the origin of the RS substrates. Other substrates (e.g. pectin) have been shown to give high proportions of acetic acid in rats, while guar gum yielded high proportions of propionic acid (Brighenti et al. 1989; Berggren et al. 1993).

Up to now, SCFA patterns formed from fermentation have been studied mainly using single substrates. Few studies are at hand regarding the potential impact of the nature of the substrate, or whether or not the substrate is one of a mixture, which is more relevant to the human diet (Hara et al. 1994; Campbell et al. 1997). Previously, it was shown that the percentage of butyric acid in the rat caecum was 18-21 with diets composed of a mixed source of indigestible carbohydrates (pea (Pisum sativum) fibre, oat bran and pectin; AM Berggren, IME Björck and EMGL Nyman, unpublished results), which was considerably higher than when the same carbohydrates were tested as single substrates: pea fibre $(11 \%)$, oat bran $(9 \%)$ and pectin (7\%; Berggren et al. 1993). Other researchers have also demonstrated a synergistic effect of a combination of carbohydrates on butyrate yield. Thus, Topping et al. (1985) reported that a mixture of gum arabic and cellulose was more efficient in generating butyric acid in the rat than the individual substrates. Furthermore, fermentation of the pericarp and aleurone in wheat bran generated a higher mass of butyrate in the rat than the individual fractions (Cheng et al. 1987).

In the present study rats were used as a model for fermentation in man, and the content of SCFA were measured at different sites along the hindgut. Although rats are caecum fermenters, the degree of fermentation of a variety of dietary fibres has been shown to correlate well between rat and man (Nyman et al. 1986). Further, there are similarities in fermentability and SCFA pattern when comparing in vitro fermentation data for different dietary fibres, using rat and human faecal inocula (Barry et al. 1995).

The purpose of the present investigation was to study the fermentability and hindgut SCFA content and distribution in rats fed bean-flour diets. The red kidney beans (Phaseolus vulgaris L.) were processed to yield flours varying in distribution of indigestible carbohydrates (i.e. RS, NSP and NDO) and botanical microstructure.

\section{Materials and methods}

\section{Materials}

The raw material used was red kidney beans from $A B$ Risenta (Stockholm, Sweden). One batch of beans was processed in different ways in order to obtain four precooked flours, as follows. Two of the bean flours varied with respect to the integrity of the cells and either contained more or less intact cells (intact-cell flour; ICF), or was completely devoid of cell structure (damaged-cell flour; DCF). The two other materials were autoclaved and either freeze-dried with the boiling water included to retain NDO (high-oligosaccharide flour; HOF) or drained to partly remove soluble components such as NDO (lowoligosaccharide flour; LOF).

\section{Processing of the flours}

ICF was prepared in following manner. Beans were soaked in twice their weight of water for $20 \mathrm{~min}$ at room temperature and drained. Then the soaked seeds were boiled for $70 \mathrm{~min}$ in a water-bath, with seed-water being 1:3 (w/v). The beans, along with the boiling water, were freeze-dried and ground to pass a $1 \mathrm{~mm}$ screen in a Cyclotec 1093 mill (Tecator AB, Höganäs, Sweden). The resulting flour was kept in a desiccator until used.

DCF was obtained from beans that were soaked in twice their weight of water for $20 \mathrm{~min}$ at room temperature and drained. The soaked seeds were ground to pass a $1 \mathrm{~mm}$ screen in a Cyclotec 1093 mill. This rough treatment resulted in breakage of the cell walls in the beans. The milled beans were boiled for $70 \mathrm{~min}$ in water-bath, with seed-water being 1:6 (w/v). The beans, together with the boiling water, were freeze-dried and then again ground to pass a $1 \mathrm{~mm}$ screen in a Cyclotec 1093 mill. The resulting flour was kept in a desiccator until used.

HOF was obtained in following manner. Unsoaked beans were autoclaved for $20 \mathrm{~min}(69 \mathrm{kPa})$, with seed-water being 1:5 (w/v). Then the beans, along with the cooking water (containing NDO), were freeze-dried and ground to pass a $1 \mathrm{~mm}$ screen in a Cyclotec 1093 mill. The resulting flour was kept in a desiccator until used.

LOF was prepared by first soaking the beans in water $(1: 3, \mathrm{w} / \mathrm{v})$ for $12 \mathrm{~h}$ at room temperature and then draining them. The soaked beans were autoclaved for $20 \mathrm{~min}$ $(69 \mathrm{kPa})$, with seed-water being 1:5 (w/v). The autoclaved beans were drained to remove the extracted oligosacharides, freeze-dried and ground to pass a $1 \mathrm{~mm}$ screen in a Cyclotec 1093 mill. The resulting flour was kept in a desiccator until used.

\section{Animals and experimental diets}

Male Wistar rats (B \& K Universal, Stockholm, Sweden) with an initial weight of $79 \pm 5 \mathrm{~g}$ were divided into groups, seven per diet, and housed individually in metabolism cages that minimised the risk of coprophagy (Berggren et al. 1993). The feed intake was restricted to $12 \mathrm{~g}$ (dry weight basis; dwb)/d. After an adaptation period of $7 \mathrm{~d}$, faeces were collected daily during a $5 \mathrm{~d}$ balance period. Faeces were kept at $-20^{\circ} \mathrm{C}$ and then freeze-dried and milled before analysis. On the final day of the balance experiment, the animals were killed with $\mathrm{CO}_{2}$, and caecum and proximal and distal colons were removed. The $\mathrm{pH}$ of the caecal contents was measured before transferring the gastrointestinal contents to a freezer. The animal experiment was 
approved by the Ethics Committee for Animal Studies at Lund University.

To study the potential impact of differences in the distribution of various kinds of indigestible carbohydrate on hindgut SCFA production, diets were prepared from the various bean flours. The diets were prepared to give two levels of indigestible carbohydrates, about $90 \mathrm{~g} / \mathrm{kg}$ $(\mathrm{dwb})$ and $120 \mathrm{~g} / \mathrm{kg}$ (dwb) respectively (Table 1).

Six bean-flour diets were prepared of which four (prepared from ICF, DCF, HOF and LOF) contained the low concentration of indigestible carbohydrates (approximately $90 \mathrm{~g} / \mathrm{kg}$; dwb). Further, raffinose (30 g/kg; dwb) was added to one of the bean flours, LOF, yielding a diet with a proportionally higher content of oligosaccharides, and a final concentration of indigestible carbohydrates of $120 \mathrm{~g} / \mathrm{kg}$ (dwb). This diet was compared with a diet containing ICF at a higher concentration of indigestible carbohydrates (approximately $120 \mathrm{~g} / \mathrm{kg}$; dwb; Table 1). In addition to the protein present in the beans, casein (Sigma Chemical Company, St Louis, MO, USA) was added to give a final level of $120 \mathrm{~g} / \mathrm{kg}(\mathrm{dwb})$. The DM content of the diets was adjusted with wheat starch, a starch source that can be expected to be completely digested and absorbed in the rat small intestine (Björck et al. 1987), and thus not contribute to hindgut fermentation.

\section{Analytical methods}

Scanning electron microscopy. The bean flours were studied at cell level with scanning electron microscopy. Flours were mounted on Al specimen stubs with doublesided sticky tape, coated with $\mathrm{Au}-\mathrm{Pd}$ in a Polaron E5500 diodsputter (Polaron Range, East Grinstead, UK), and examined in a JEOL T330 Scanning electron microscope (JEOL, Tokyo, Japan), operated at $10 \mathrm{kV}$.

NSP. The content of soluble and insoluble dietary fibre in the bean material was analysed gravimetrically in principle according to Asp et al. (1983). The composition of the isolated dietary fibre was analysed by GLC for the neutral sugars as their alditol acetates and by a spectrophotometric method for the uronic acids (Theander et al. 1995). The dietary fibre values were corrected for the amount of total starch present in the isolated fibre residue and referred to as NSP. The content of NSP in faeces was analysed as for the raw materials but without the gravimetric step.

Starch. Total starch content in the raw materials (bean flours and gravimetric dietary fibre residues) and in faeces from the rats was analysed as liberated glucose after solubilisation in $\mathrm{KOH}$ and enzymic treatment with a thermostable $\alpha$-amylase (Termamyl 300L DX; Novo Nordisk A/S, Copenhagen, Denmark) and amyloglucosidase (Björck \& Siljeström, 1992) with one modification. Thus, the sample was suspended in $10 \mathrm{ml} 0 \cdot 1 \mathrm{M}$-phosphate buffer ( $\mathrm{pH} \mathrm{6.0)} \mathrm{instead} \mathrm{of} \mathrm{water,} \mathrm{in} \mathrm{the} \mathrm{first} \mathrm{incubation} \mathrm{step.}$

The amount of RS in the bean flours was analysed using an in vitro model (Åkerberg et al. 1998) Six human subjects chewed glass beads and rinsed their mouth with $5 \mathrm{ml}$ water, and thereafter the saliva was pooled. Five $\mathrm{ml}$ of pooled saliva was transferred to a beaker containing the test product and water. The $\mathrm{pH}$ was adjusted to 1.5 and pepsin was added. Thereafter the samples were incubated at $37^{\circ} \mathrm{C}$ for $30 \mathrm{~min}$. The $\mathrm{pH}$ was adjusted to 5.0 after addition of pancreatin and amyloglucosidase. The suspension was incubated for $16 \mathrm{~h}$ at $40^{\circ} \mathrm{C}$, and undigested starch was precipitated with ethanol and analysed as above (Björck \&

Table 1. Composition ( $\mathrm{g} / \mathrm{kg}$; dry weight basis) and distribution (\%) of various types of indigestible carbohydrates in test diets containing four flours prepared from red kidney bean (Phaseolus vulgaris) by different procedures†

\begin{tabular}{|c|c|c|c|c|c|c|}
\hline & \multicolumn{2}{|c|}{$\begin{array}{l}\text { High-level diets } \\
\quad(120 \mathrm{~g} / \mathrm{kg})\end{array}$} & \multicolumn{4}{|c|}{$\begin{array}{l}\text { Low-level diets } \\
\quad(90 \mathrm{~g} / \mathrm{kg})\end{array}$} \\
\hline & ICF & LOF + raffinose & ICF & DCF & HOF & LOF \\
\hline \multicolumn{7}{|l|}{ Ingredients (g/kg) } \\
\hline Bean flour & 332 & 332 & 251 & 332 & 332 & 332 \\
\hline Raffinose & - & 30 & - & - & - & - \\
\hline Casein & 38 & 35 & 58 & 39 & 35 & 35 \\
\hline Basal diet mixture* & 209 & 209 & 209 & 209 & 209 & 209 \\
\hline Wheat starch & 421 & 394 & 482 & 420 & 424 & 424 \\
\hline \multicolumn{7}{|c|}{ Indigestible carbohydrate composition } \\
\hline Total amount $(\mathrm{g} / \mathrm{kg})$ & 123 & 120 & 93 & 86 & 88 & 89 \\
\hline RS (\%) & 42 & 13 & 42 & 16 & 16 & 17 \\
\hline Soluble NSP (\%) & 11 & 20 & 11 & 18 & 27 & 27 \\
\hline Insoluble NSP (\%) & 34 & 35 & 34 & 48 & 39 & 46 \\
\hline NDO (\%) & 13 & 32 & 13 & 18 & 18 & 10 \\
\hline
\end{tabular}

DCF, damaged-cell flour; HOF, high-oligosaccharide flour; ICF, intact-cell flour; LOF, lowoligosaccharide flour; NDO, non-digestible oligosaccharides; RS, resistant starch.

* Contained $(\mathrm{g} / \mathrm{kg}): 100$ sucrose, 50 maize oil, 1.2 DL-methionine (Sigma Chemical Company, St Louis, MO, USA), 2 choline chloride (Aldrich-Chemie, Steinheim, Germany), 48 mineral mixture (containing $(\mathrm{g} / \mathrm{kg})$ : $\mathrm{CuSO}_{4} .5 \mathrm{H}_{2} \mathrm{O} 0.37, \mathrm{ZnSO}_{4} .7 \mathrm{H}_{2} \mathrm{O} 1.4, \mathrm{KH}_{2} \mathrm{PO}_{4} 332 \cdot 1, \mathrm{NaH}_{2} \mathrm{PO}_{4} .2 \mathrm{H}_{2} \mathrm{O} 171 \cdot 8$, $\mathrm{CaCO}_{3} 324.4, \mathrm{KI} 0.068, \mathrm{MgSO}_{4} 57.2, \mathrm{FeSO}_{4} .7 \mathrm{H}_{2} \mathrm{O} 7 \cdot 7, \mathrm{MnSO}_{4} \cdot \mathrm{H}_{2} \mathrm{O} 3.4, \mathrm{CoCl} 6 \mathrm{H}_{2} \mathrm{O} 0.020, \mathrm{NaCl}$ $101.7)$, 8 vitamin mixture (containing $(\mathrm{g} / \mathrm{kg}$ ): menadione 0.62 , thiamine hydrochloride 2.5 , riboflavin $2 \cdot 5$, pyridoxine hydrochloride $1 \cdot 25$, calcium pantothenate $6 \cdot 25$, nicotinic acid $6 \cdot 25$, folic acid 0.25 , inositol $12.5, p$-aminobenzoic acid 1.25 , biotin 0.05 , cyanocobalamin 0.00375 , vitamin $A$ $0 \cdot 19$, vitamin D 0.000613, vitamin E 25, maize starch 941.25).

†For details of procedures, see p. 380 . 
Siljeström, 1992). Pooled saliva was used instead of an initial chewing of the sample since the product was not realistic food item but a dry flour. The analysis was performed in triplicate.

Total starch detected in faeces, when corrected for free glucose analysed with a glucose oxidase/peroxidase reagent, was regarded as resistant (Björck \& Siljeström, 1992). The analysis was preformed in duplicate. The amount of free glucose in faeces was very small and less than $12 \%$ of the total $\alpha$-glucan in faeces was glucose.

In vitro rate of starch hydrolysis. The in vitro rate of starch hydrolysis in ICF and DCF was measured according to Granfeldt et al. (1992). The rate of appearance of starch degradation products was analysed in the dialysate following sequential incubation with pooled saliva, pepsin and $\alpha$-amylase. The analysis was preformed in triplicate.

Low-molecular-weight carbohydrates. The content of raffinose, stachyose and verbascose in the bean flours and in representative samples of the rat faeces, was analysed according to Nygaard Johansen et al. (1996). Lowmolecular-weight carbohydrates were extracted from $1 \mathrm{~g}$ sample in boiling water for $30 \mathrm{~min}$ and quantified by highperformance anion-exchange chromatography with pulsed ampereometric detection, using a Dionex DX 500 chromatography system Dionex, Sunnyvale, CA, USA. The analytical column was a CarboPac PA $10(4 \times 250 \mathrm{~mm})$ (Dionex) and a PA 10 Guard column $(4 \times 50 \mathrm{~mm})$ was also installed. Arabinose was used as internal standard $(5.0 \mathrm{mg} / \mathrm{l})$. Before injection, the samples were cleaned by filtering through Millex ${ }^{\circledR}$-HV filters $(0.45 \mu \mathrm{m}$; Millipore, Bedford, MA, USA) and on Guard-A (Dionex) to remove peptides. Water and $300 \mathrm{~mm}-\mathrm{NaOH}$ were used as eluents with a flow rate of $1.0 \mathrm{ml} / \mathrm{min}$.

Protein. The amount of $\mathrm{N}$ in the bean flours was determined by the Kjeldahl method (Association of Official Analytical Chemists, 1984). The amount of protein was calculated as $\mathrm{N} \times 6 \cdot 25$.

Short-chain fatty acids. A GLC method was used to analyse the SCFA (formic, acetic, propionic, isobutyric, butyric, isovaleric, valeric, caproic and heptanoic acid) and succinic acid in caecal and colonic contents (Richardson et al. 1989). The intestinal content was homogenised (a)

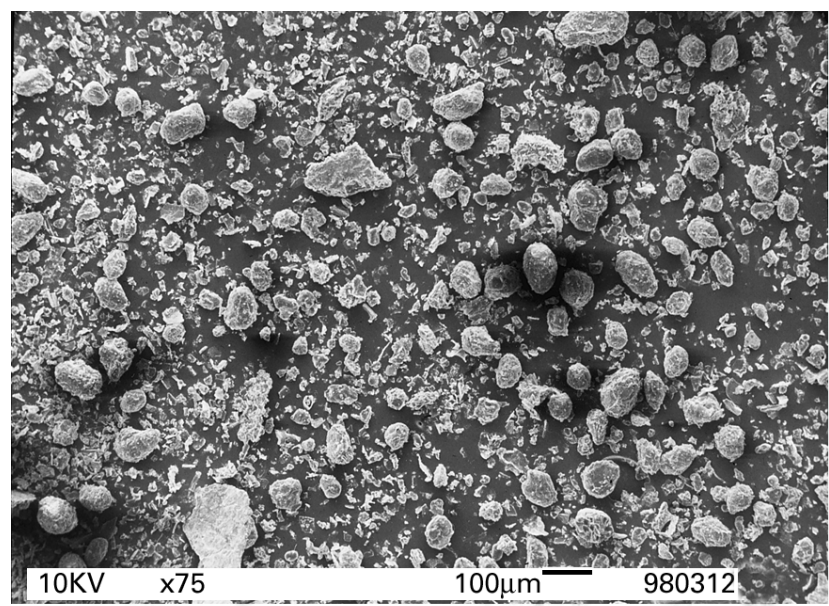

(c)

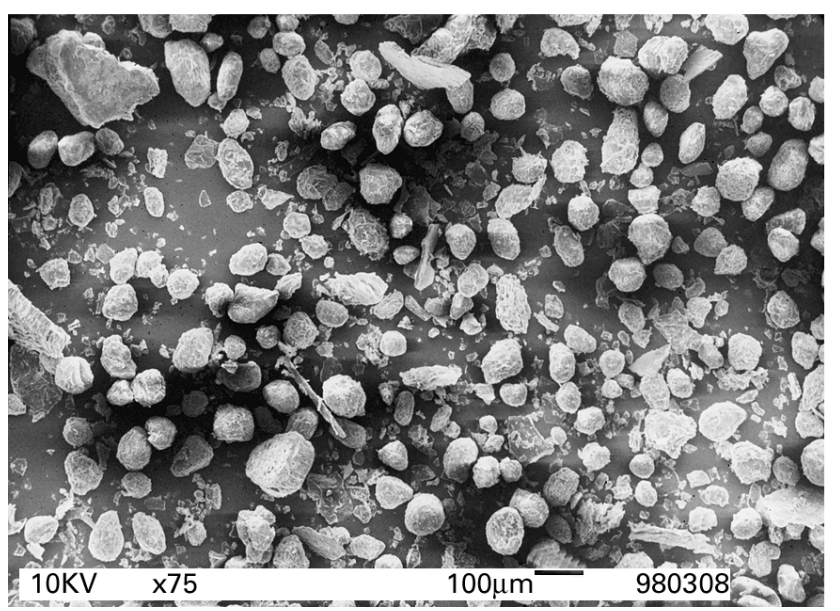

(b)

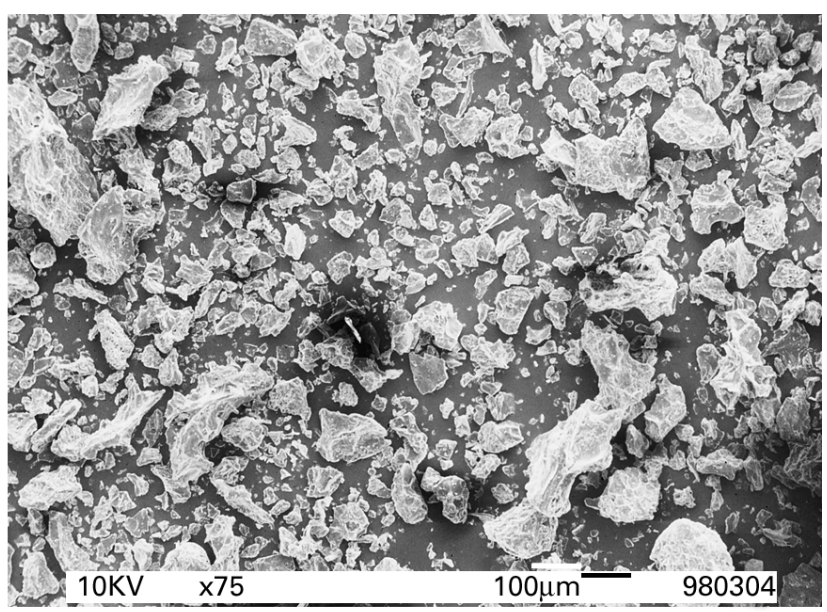

(d)

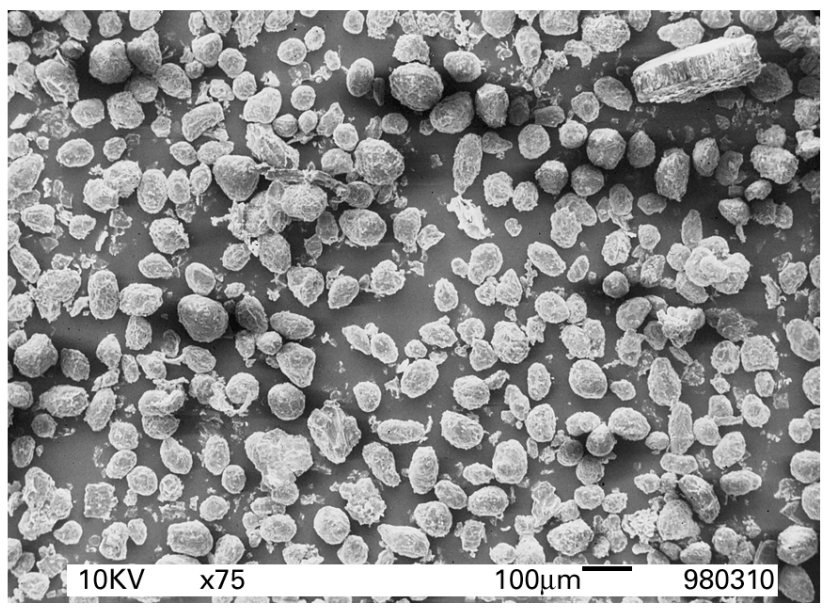

Fig. 1. Scanning electron micrographs of four flours prepared by different procedures from red kidney bean (Phaseolus vulgaris). (a) Intactcell flour, (b) damaged-cell flour, (c) high-oligosaccharide flour, (d) low-oligosaccharide flour. For details of procedures, see pp. 380-383. magnification $\times 75$. 
(Polytron ${ }^{\circledR}$; Kinematica, Luzern, Switzerland) with 2-ethylbutyric acid (internal standard). $\mathrm{HCl}$ was added to protonise the SCFA, which were then extracted with diethylether and silylated with $n$-(tert-butyldimethylsilyl)- $n$-methyltrifluoroacetamide (MTBSTFA; Sigma Chemical Company). The samples were allowed to stand for $24 \mathrm{~h}$ to complete derivatization before injection on a HP-5 column (HewlettPackard Corp., Wilmington, DE, USA).

\section{Calculations and statistical evaluation}

Total fermentability of the indigestible carbohydrates was calculated as the amount of carbohydrates excreted in faeces divided by the ingested amount of indigestible carbohydrates.

The caecal concentration of SCFA were corrected for the small differences in feed intake and extrapolated to a complete intake of the diet.

All statistical analyses were performed with the Minitab ${ }^{\circledR}$ statistical software package version 12.2 (Minitab Inc, State College, PA, USA). The means were analysed by ANOVA using the general linear model procedure according to Minitab $^{\circledR}$. Significance of difference between the means was determined by multiple comparison of Tukey's. The level of significance was $P<0.05$.

\section{Results}

\section{Scanning electron microscopy of the bean flours}

Scanning electron microscopy indicated that the ICF contained structures $(75-100 \mu \mathrm{m})$ corresponding to intact cells (Fig. 1a). In contrast, the DCF was essentially devoid of such structures (Fig. 1b), suggesting that the milling of raw beans resulted in an extensive cell damage. The autoclaved bean flours HOF (Fig. 1c) and LOF (Fig. 1d) seemed to contain mainly intact cells.

\section{In vitro starch hydrolysis}

The course of in vitro starch hydrolysis for ICF and DCF is shown in Fig. 2. The rate of hydrolysis was considerably

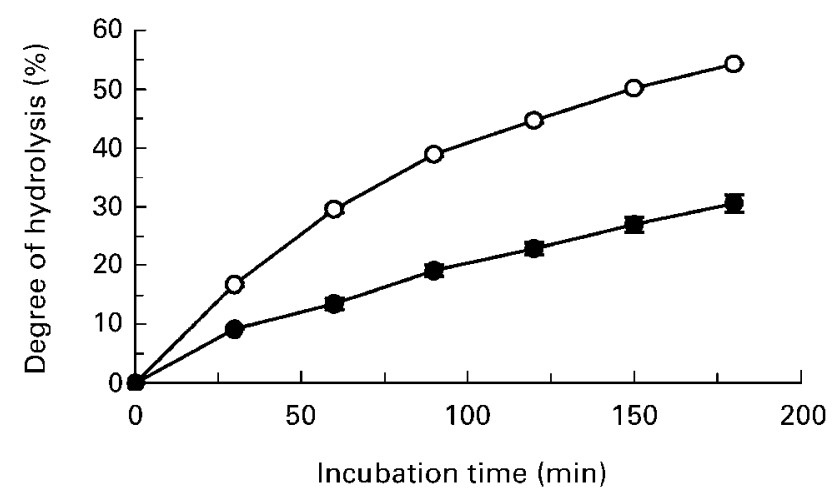

Fig. 2. In vitro hydrolysis of starch in intact-cell flour $(\bullet)$ and damaged-cell flour $(O)$ prepared by different procedures from red kidney bean (Phaseolus vulgaris). For details of procedures, see p. 380.
Table 2. Content of carbohydrates $(\mathrm{g} / \mathrm{kg} ; \mathrm{dwb})$ in the four flours prepared by different procedures from red kidney bean (Phaseolus vulgaris $) \dagger$

\begin{tabular}{lrrrr}
\hline Bean flour... & ICF & DCF & HOF & LOF \\
\hline Total starch & $421^{\mathrm{a}}$ & $411^{\mathrm{b}}$ & $405^{\mathrm{b}}$ & $435^{\mathrm{c}}$ \\
RS & $154^{\mathrm{a}}$ & $42^{\mathrm{b}}$ & $42^{\mathrm{b}}$ & $47^{\mathrm{b}}$ \\
Total NSP: Soluble & $42^{\mathrm{a}}$ & $46^{\mathrm{b}}$ & $71^{\mathrm{c}}$ & $71^{\mathrm{c}}$ \\
Insoluble & $126^{\mathrm{a}}$ & $125^{\mathrm{a}}$ & $104^{\mathrm{bc}}$ & $125^{\mathrm{ac}}$ \\
Rhamnose: Soluble & $1^{\mathrm{a}}$ & $1^{\mathrm{a}}$ & $4^{\mathrm{b}}$ & $4^{\mathrm{b}}$ \\
Insoluble & $5^{\mathrm{a}}$ & $5^{\mathrm{a}}$ & $2^{\mathrm{b}}$ & $2^{\mathrm{b}}$ \\
Fucose: Soluble & $2^{\mathrm{a}}$ & $1^{\mathrm{a}}$ & $4^{\mathrm{b}}$ & $4^{\mathrm{b}}$ \\
Insouble & $4^{\mathrm{a}}$ & $4^{\mathrm{a}}$ & $1^{\mathrm{b}}$ & $1^{\mathrm{b}}$ \\
Arabinose: Soluble & $14^{\mathrm{a}}$ & $18^{\mathrm{b}}$ & $17^{\mathrm{b}}$ & $18^{\mathrm{b}}$ \\
$\quad$ Insoluble & $30^{\mathrm{a}}$ & $27^{\mathrm{ab}}$ & $26^{\mathrm{b}}$ & $29^{\mathrm{ab}}$ \\
Xylose: Soluble & $5^{\mathrm{a}}$ & $6^{\mathrm{b}}$ & $10^{\mathrm{c}}$ & $10^{\mathrm{c}}$ \\
Insoluble & $15^{\mathrm{a}}$ & $15^{\mathrm{a}}$ & $11^{\mathrm{b}}$ & $13^{\mathrm{c}}$ \\
Mannose: Soluble & $0^{\mathrm{a}}$ & $0^{\mathrm{a}}$ & $6^{\mathrm{b}}$ & $6^{\mathrm{b}}$ \\
Insoluble & $5^{\mathrm{a}}$ & $5^{\mathrm{a}}$ & $1^{\mathrm{b}}$ & $1^{\mathrm{b}}$ \\
Galactose: Soluble & $7^{\mathrm{a}}$ & $7^{\mathrm{a}}$ & $10^{\mathrm{b}}$ & $10^{\mathrm{b}}$ \\
$\quad$ Insoluble & $8^{\mathrm{a}}$ & $9^{\mathrm{a}}$ & $4^{\mathrm{b}}$ & $4^{\mathrm{b}}$ \\
Glucose: Soluble & $1^{\mathrm{a}}$ & $1^{\mathrm{a}}$ & $7^{\mathrm{b}}$ & $7^{\mathrm{b}}$ \\
Insoluble & $43^{\mathrm{a}}$ & $45^{\mathrm{a}}$ & $45^{\mathrm{a}}$ & $57^{\mathrm{a}}$ \\
Uronic acids: Soluble & $12^{\mathrm{a}}$ & $12^{\mathrm{a}}$ & $13^{\mathrm{a}}$ & $12^{\mathrm{a}}$ \\
$\quad$ Insoluble & $16^{\mathrm{a}}$ & $17^{\mathrm{ac}}$ & $14^{\mathrm{b}}$ & $18^{\mathrm{c}}$ \\
Total NDO $\quad 7^{\mathrm{a}}$ & $46^{\mathrm{a}}$ & $47^{\mathrm{a}}$ & $26^{\mathrm{b}}$ \\
Raffinose & $2^{\mathrm{a}}$ & $2^{\mathrm{a}}$ & $2^{\mathrm{a}}$ & $1^{\mathrm{b}}$ \\
Stachyose & $43^{\mathrm{a}}$ & $42^{\mathrm{a}}$ & $42^{\mathrm{a}}$ & $24^{\mathrm{b}}$ \\
Verbascose & $2^{\mathrm{a}}$ & $2^{\mathrm{a}}$ & $3^{\mathrm{c}}$ & $1^{\mathrm{d}}$ \\
\hline
\end{tabular}

ICF, intact-cell flour; DCF, damaged-cell flour; HOF, high-oligosaccharide flour; LOF, low-oligosaccharide flour; dwb, dry weight basis; RS, resistant starch; NDO, non-digestible oligosaccharides.

a,b,c Mean values $(n 3)$ in the same row with different superscript letters were significantly different $(P<0.01)$

†For details of procedures, see p. 380.

lower for ICF than for DCF, and after 180 min the starch in ICF was $30 \%$ hydrolysed, compared with $54 \%$ in DCF. The rate of in vitro starch hydrolysis was not measured in $\mathrm{HOF}$ and LOF.

\section{Content of indigestible carbohydrates in the bean flours}

The content ( $\mathrm{g} / \mathrm{kg}$; dwb) of RS, soluble and insoluble NSP and NDO (raffinose, stachyose and verbascose) in the bean flours is listed in Table 2.

The amount of RS was considerably higher in the ICF than in the other three bean flours. The total amount of NSP was similar for ICF, DCF and HOF (on average $171 \mathrm{~g} / \mathrm{kg}$; dwb), whereas that of LOF was somewhat higher $(196 \mathrm{~g} / \mathrm{kg}$; $\mathrm{dwb}$ ). The apparently higher NSP content in LOF was due to a loss of DM, mainly NDO and other low-molecular-weight carbohydrates, when the beans were drained. Of the total NSP, approximately $26 \%$ was soluble in the boiled-bean flours (ICF and DCF) $v$. about $38 \%$ in the autoclaved flours (HOF and LOF). The main constituents in the soluble-NSP fraction were arabinose, uronic acids and some galactose. The insoluble NSP consisted mainly of glucose and arabinose, but considerable amounts of uronic acids, galactose and xylose were also detected. The overall composition of NSP was similar in the two boiled-bean flours (ICF and DCF). A significantly higher amount $(P=0.0001)$ of soluble arabinans was, however found for DCF. With autoclaving there was a solubilization of all 
NSP components, except for those containing uronic acids and arabinose.

The content of NDO was between 26 and $47 \mathrm{~g} / \mathrm{kg}$ in the different flours. The main component in all flours was stachyose, comprising about $91 \%$ total NDO. The LOF (the flour for which the beans had been drained following autoclaving) contained $56 \%$ of the NDO originally present.

\section{Distribution of indigestible carbohydrates in the test diets}

High-level diets (120 g indigestible carbohydrates/ $\mathrm{kg}$ ). RS formed a higher percentage of the indigestible carbohydrates in the ICF diet (42) compared with $\mathrm{LOF}+$ raffinose diet (13; Table 1). This diet instead contained more NDO (32\% v. $13 \%)$ and soluble NSP (20\% v. $11 \%)$. Both diets had similar amounts of insoluble NSP (34\% indigestible carbohydrates).

Low-level diets (90 $\mathrm{g}$ indigestible carbohydrates $/ \mathrm{kg}$ ). A higher percentage of the indigestible carbohydrates was RS in the ICF diet $(42 \%)$ than in the other diets $(16-17)$. DCF and HOF diets had a similar composition of indigestible carbohydrates, both with comparatively high percentages of NDO (18) and NSP (66). However, the amount of soluble NSP was higher in the HOF diet. Further, microstructure of the two diets differed, with HOF displaying an apparently intact cell structure (Fig. 1(c)) and DCF a disrupted cell structure (Fig. 1(b)). The LOF diet had the lowest amount of NDO, $10 \%$ total indigestible carbohydrates compared with $13-18 \%$ total indigestible carbohydrates in the other diets. The differences in the contents of RS and NDO in the four diets resulted in various contents of NSP. Thus, the percentage of NSP was lower in ICF (45) compared with the other test diets (66-73).

\section{Fermentability in the rat hindgut}

The fermentability of the indigestible carbohydrates in the beans was generally high, and averaged 80-87\% (Table 3). However, the different constituents were fermented to different extents.

High-level diets (120 g indigestible carbohydrate/kg). $\mathrm{RS}$ was fermented to a higher extent in the ICF diet than in the diet $\mathrm{LOF}+$ raffinose (only $3 \%$ was excreted compared with $14 \%$ in the diet LOF + raffinose). Of total NSP about $26 \%$ was excreted, and arabinose-containing polysaccharides were fermented to the highest extent in both diets, only about $7 \%$ being recovered in faeces. The other main components were less fermented and of the polymers containing xylose and uronic acids; 14-21\% of the ingested amounts were excreted in faeces, with no differences between diets. Interestingly, the excretion of NSP-glucose in faeces was significantly higher $(P=0.037)$ with the ICF $(61 \%)$ than with the LOF + raffinose diet (46\%). No NDO was detected in the faeces, and these substances were therefore assumed to be completely fermented.

Low-level diets (90 $\mathrm{g}$ indigestible carbohydrates $/ \mathrm{kg})$. RS in the ICF diet was almost completely fermented, with only $1 \%$ being recovered in faeces, which was significantly lower $(P=0.0004)$ than that with the LOF diet, where $9 \%$ was recovered. $\mathrm{RS}$ in the DCF diet was also almost completely fermented, and $<3 \%$ of the intake was excreted.

The fermentability of total NSP was similar to that with the high-level diets. Thus, approximately $25 \%$ of the total NSP was excreted in all groups. Furthermore, arabinosecontaining polysaccharides were fermented to a high extent in all diets (mean of $5 \%$ was excreted), whereas xylose- and uronic acid-containing polysaccharides were somewhat less

Table 3. Faecal recovery of indigestible carbohydrates (\% intake) in rats given test diets containing flours prepared by different procedures from red kidney bean (Phaseolus vulgaris) $\dagger$

(Values are means with their standard errors for seven rats per diet)

\begin{tabular}{|c|c|c|c|c|c|c|c|c|c|c|c|c|}
\hline & \multicolumn{4}{|c|}{$\begin{array}{l}\text { High-level diets } \\
\text { (120 g/kg; dwb) }\end{array}$} & \multicolumn{8}{|c|}{$\begin{array}{l}\text { Low-level diets } \\
\text { (90 g/kg; dwb) }\end{array}$} \\
\hline & \multicolumn{2}{|c|}{ ICF } & \multicolumn{2}{|c|}{$\begin{array}{l}\text { LOF + } \\
\text { raffinose }\end{array}$} & \multicolumn{2}{|c|}{ ICF } & \multicolumn{2}{|c|}{ DCF } & \multicolumn{2}{|c|}{ HOF } & \multicolumn{2}{|c|}{ LOF } \\
\hline & Mean & SE & Mean & SE & Mean & SE & Mean & SE & Mean & SE & Mean & SE \\
\hline RS $\ddagger$ & 3 & 1 & $14^{*}$ & 6 & $1^{\mathrm{a}}$ & 1 & $3^{a}$ & 1 & $5^{\mathrm{ab}}$ & 1 & $9^{b}$ & 2 \\
\hline NSP: Total & 27 & 2 & 25 & 2 & $26^{a}$ & 1 & $26^{a}$ & 2 & $23^{a}$ & 2 & $25^{\mathrm{a}}$ & 2 \\
\hline Rhamnose & 32 & 2 & 32 & 2 & $35^{\mathrm{a}}$ & 3 & $26^{\mathrm{a}}$ & 2 & $26^{\mathrm{a}}$ & 1 & $23^{a}$ & 1 \\
\hline Fucose & 12 & 1 & 12 & 1 & $12^{\mathrm{a}}$ & 1 & $13^{\mathrm{a}}$ & 1 & $11^{\mathrm{a}}$ & 1 & $11^{\mathrm{a}}$ & 1 \\
\hline Arabinose & 7 & 1 & 6 & 1 & $6^{a}$ & 1 & $5^{\mathrm{a}}$ & 1 & $4^{a}$ & 1 & $6^{a}$ & 1 \\
\hline Xylose & 18 & 3 & 14 & 2 & $18^{\mathrm{a}}$ & 1 & $13^{\mathrm{a}}$ & 2 & $13^{a}$ & 2 & $15^{\mathrm{a}}$ & 2 \\
\hline Mannose & 32 & 2 & $12^{\star \star \star}$ & 1 & $31^{\mathrm{a}}$ & 2 & $14^{\mathrm{b}}$ & 1 & $9^{c}$ & 1 & $10^{\mathrm{bc}}$ & 1 \\
\hline Galactose & 15 & 1 & $23^{*}$ & 3 & $17^{\mathrm{a}}$ & 1 & $16^{\mathrm{a}}$ & 1 & $15^{\mathrm{a}}$ & 1 & $16^{\mathrm{a}}$ & 1 \\
\hline Glucose & 61 & 6 & $46^{*}$ & 4 & $59^{a b}$ & 3 & $63^{a}$ & 4 & $48^{\mathrm{b}}$ & 4 & $50^{\mathrm{ab}}$ & 4 \\
\hline Uronic acids & 19 & 2 & 21 & 3 & $17^{\mathrm{a}}$ & 2 & $17^{\mathrm{a}}$ & 2 & $19^{a}$ & 2 & $23^{a}$ & 3 \\
\hline NDO & $-\S$ & & $-\S$ & & $-\S$ & & $-\S$ & & $-\S$ & & $-\S$ & \\
\hline Total & 13 & 1 & 15 & 2 & 13 & 1 & 17 & 2 & 16 & 1 & 20 & 2 \\
\hline
\end{tabular}

ICF, intact-cell flour; LOF, low-oligosaccharide flour; DCF, damaged-cell flour; HOF, high-oligosaccharide flour; NDO, non-digestible oligosaccharides; RS, resistant starch.

a,b,c Mean values in the same row with different superscript letters were significantly different $(P<0.05)$

Mean values were significantly different from those for diet ICF: ${ }^{*} P<0.05$, ${ }^{\star \star \star} P<0.001$.

†For details of diets and procedures, see Table 1 and p. 380.

$\ddagger$ Faecal recovery of RS was calculated as RS in faeces:RS intake.

$\S$ Not calculated as no NDO was detected in faeces. 
fermented, and between 13 and $23 \%$ of the ingested amounts were excreted. NSP-glucans were more resistant and 48-63\% were excreted. Less NSP-glucans appeared to be fermented with the ICF (41\%) and DCF (37\%) diets than with the $\mathrm{HOF}$ and LOF diets (52 and $50 \%$ respectively). However, only the differences between the DCF and the HOF diets were significant $(P=0 \cdot 049)$.

\section{Caecal pH}

The $\mathrm{pH}$ in the caecum varied between 6.7 and $7 \cdot 1$ (mean $6 \cdot 9)$, with no significant differences among test diets.

\section{Distribution of short-chain fatty acids in rat hindgut}

The total concentration and distribution of SCFA throughout the hindgut is shown in Table 4. The main SCFA formed were acetic, propionic and butyric acid, and $92 \%$ of the SCFA could be attributed to these acids.

High-level diets (120 g indigestible carbohydrate $/ \mathrm{kg})$. The distribution between acetic, propionic and butyric acids in caecal contents was on average 71, 12 and $17 \%$ respectively, with no significant difference between the two diets (Table 4). In the proximal colon the percentage of acetic acid was higher and those of propionic and butyric acids were lower ( 80,8 and $12 \%$ respectively).

In the distal colon, some differences between the diets were obtained. The ICF diet generated a significantly higher percentage of butyric acid (24) than the LOF + raffinose $\operatorname{diet}(12 ; P=0 \cdot 0005)$.

Low-level diets (90 $\mathrm{g}$ indigestible carbohydrate/ $\mathrm{kg}$ ). In the caecum acetic, propionic and butyric acids were present in a molar ratio of 69:13:18, which was similar to those for the two high-level diets. The percentage of propionic acid was significantly $(P=0 \cdot 017)$ higher with the ICF diet (15) than with the LOF diet (11). No other differences between the diets were obtained.

In proximal colon acetic, propionic and butyric acids were present in a molar ratio of 77:10:13, with no significant differences among test diets.

The percentages of acetic, propionic and butyric acids in the distal colon were on average 76,9 and 15 respectively.

Table 4. The total concentration of short-chain fatty acids (mmol/kg wet content) and the relative percentages of acetic, propionic and butyric acid in different parts of the hindgut of rats given test diets containing flours prepared by different procedures from red kidney bean (Phaseolus vulgaris $) \dagger$

(Values are means with their standard errors for seven rats per diet)

\begin{tabular}{|c|c|c|c|c|c|c|c|c|}
\hline & \multicolumn{2}{|c|}{$\begin{array}{c}\text { Acetic acid } \\
(\%)\end{array}$} & \multicolumn{2}{|c|}{$\begin{array}{l}\text { Propionic } \\
\text { acid (\%) }\end{array}$} & \multicolumn{2}{|c|}{$\begin{array}{l}\text { Butyric acid } \\
(\%)\end{array}$} & \multicolumn{2}{|c|}{$\begin{array}{c}\text { Total } \\
\text { concentration } \\
(\mathrm{mmol} / \mathrm{kg})\end{array}$} \\
\hline & Mean & SE & Mean & SE & Mean & SE & Mean & SE \\
\hline \multicolumn{9}{|c|}{ High-level diets (120 g/kg; dwb) } \\
\hline \multicolumn{9}{|c|}{ Caecum } \\
\hline ICF & 68 & 2 & 13 & 1 & 19 & 2 & 79 & 4 \\
\hline LOF+raffinose & 74 & 2 & 12 & 3 & 14 & 3 & 85 & 8 \\
\hline \multicolumn{9}{|l|}{ Proximal colon } \\
\hline ICF & 78 & 3 & 8 & 2 & 14 & 1 & 65 & 6 \\
\hline LOF+raffinose & 81 & 1 & 8 & 1 & 11 & 2 & 79 & 7 \\
\hline \multicolumn{9}{|l|}{ Distal colon } \\
\hline ICF & 66 & 2 & 10 & 1 & 24 & 2 & 74 & 8 \\
\hline LOF+raffinose & $79^{\star \star \star}$ & 2 & 9 & 2 & $12^{\star \star \star}$ & 2 & 78 & 9 \\
\hline \multicolumn{9}{|c|}{ Low-level diets (90 g/kg; dwb) } \\
\hline \multicolumn{9}{|c|}{ Caecum } \\
\hline ICF & $69^{\mathrm{a}}$ & 2 & $15^{\mathrm{a}}$ & 2 & $16^{\mathrm{a}}$ & 2 & $73^{a}$ & 7 \\
\hline DCF & $68^{\mathrm{a}}$ & 3 & $13^{\mathrm{ab}}$ & 1 & $19^{\mathrm{a}}$ & 3 & $72^{\mathrm{a}}$ & 6 \\
\hline HOF & $70^{\mathrm{a}}$ & 2 & $12^{\mathrm{ab}}$ & 1 & $18^{\mathrm{a}}$ & 2 & $81^{\mathrm{a}}$ & 10 \\
\hline LOF & $70^{\mathrm{a}}$ & 3 & $11^{\mathrm{b}}$ & 1 & $19^{\mathrm{a}}$ & 3 & $87^{\mathrm{a}}$ & 16 \\
\hline \multicolumn{9}{|l|}{ Proximal colon } \\
\hline ICF & $79^{\mathrm{a}}$ & 3 & $10^{\mathrm{a}}$ & 2 & $10^{\mathrm{a}}$ & 1 & $56^{\mathrm{a}}$ & 8 \\
\hline DCF & $76^{\mathrm{a}}$ & 2 & $10^{\mathrm{a}}$ & 1 & $14^{\mathrm{a}}$ & 2 & $63^{\mathrm{a}}$ & 7 \\
\hline HOF & $77^{\mathrm{a}}$ & 1 & $10^{\mathrm{a}}$ & 1 & $13^{\mathrm{a}}$ & 1 & $53^{\mathrm{a}}$ & 8 \\
\hline LOF & $77^{\mathrm{a}}$ & 2 & $9^{\mathrm{a}}$ & 1 & $14^{\mathrm{a}}$ & 3 & $64^{\mathrm{a}}$ & 8 \\
\hline \multicolumn{9}{|l|}{ Distal colon } \\
\hline ICF & $73^{\mathrm{a}}$ & 3 & $10^{\mathrm{a}}$ & 2 & $17^{\mathrm{a}}$ & 2 & $81^{\mathrm{a}}$ & 7 \\
\hline DCF & $74^{\mathrm{a}}$ & 1 & $10^{\mathrm{a}}$ & 1 & $16^{\mathrm{a}}$ & 1 & $81^{a}$ & 8 \\
\hline HOF & $77^{\mathrm{a}}$ & 3 & $8^{a}$ & 2 & $15^{\mathrm{a}}$ & 1 & $61^{\mathrm{a}}$ & 7 \\
\hline LOF & $79^{\mathrm{a}}$ & 2 & $9^{\mathrm{a}}$ & 2 & $12^{\mathrm{a}}$ & 2 & $78^{\mathrm{a}}$ & 6 \\
\hline
\end{tabular}

ICF, intact-cell flour; LOF, low-oligosaccharide flour; DCF, damaged-cell flour; HOF, high-oligosaccharide flour.

${ }^{a, b}$ Mean values along the hindgut and within the same part of the hindgut with different superscript letters were significantly different $(P<0.05)$.

Mean values along the hindgut and within the same part of the hindgut (i.e. caecum, proximal colon or distal colon) were significantly different from the corresponding values for diet ICF: ${ }^{\star * \star} P<0.001$.

†For details of diets and procedures, see Table 1 and p. 380. 
ICF yielded the highest percentage of butyric acid (17), but was not significantly different from the other low-level diet.

\section{Concentration of short-chain fatty acids along the hindgut}

The concentration of acetic acid was similar throughout the hindgut with most diets; the only exception was the HOF diet, for which the concentration was higher $(P=0.034)$ in the caecum than in the proximal colon. The concentration of propionic acid tended to be lower in the colon than in the caecum. This gradient was significant in the proximal colon $(P<0.05)$ for all diets, except for diets $\mathrm{LOF}+$ raffinose and ICF at the lower level. For the HOF diet the concentration of propionic acid was also significantly lower $(P=0 \cdot 0004)$ in the distal colon than in the caecum.

The concentration of butyric acid along the hindgut varied for different diets (Fig. 3). Thus, in the case of DCF and $\mathrm{LOF}+$ raffinose diet the concentration of butyric acid was similar along the hindgut, and with the HOF and LOF diet it decreased in the distal colon compared with the caecum $(P<0.05)$. Interestingly, for the diets containing ICF, the butyric acid concentration was higher in the distal colon compared with the proximal colon $(P=0.009$ for ICF at the higher level and $P=0.047$ for ICF at the lower level). This increased concentration of butyric acid in the distal colon was found only for these two diets, both containing considerably more RS (Table 1) than the other diets.

\section{Discussion}

\section{Evaluation of the bean flours}

The limited availability of starch in vitro and the high content of RS in ICF were probably attributed to the physical encapsulation of starch granules within cell walls in the ICF. Physically-inaccessible starch entrapped within intact plant cells are defined as $\mathrm{RS}_{1}$ by Englyst et al. (1992). As legumes are characterised by a relatively high amylose content (Hoover \& Sosulski, 1991), and the fact that the beans in ICF were boiled using a small amount of water

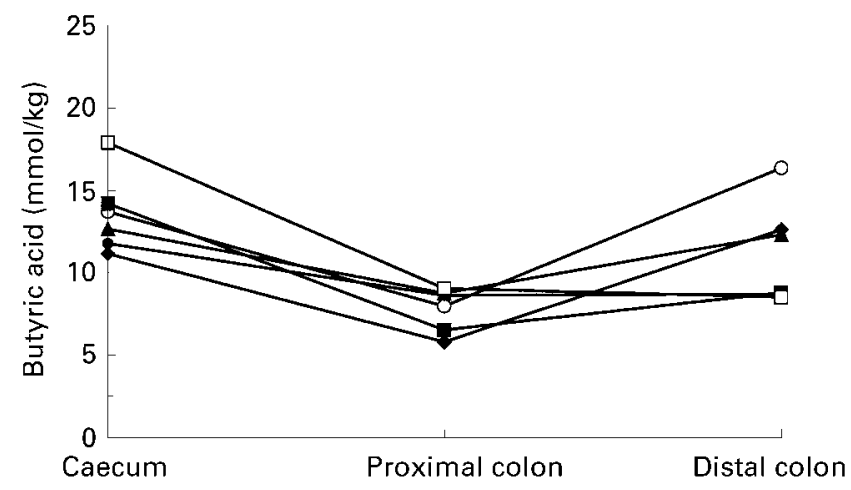

Fig. 3. Concentration of butyric acid (mmol/kg wet contents) along the hindgut of rats given test diets containing flours prepared by different procedures from red kidney bean (Phaseolus vulgaris) at either approximately $120 \mathrm{~g} / \mathrm{kg}((\bigcirc)$, intact-cell flour; (๑), low-oligosaccharide flour + raffinose), or approximately $90 \mathrm{~g} / \mathrm{kg}((\bullet)$, intact-

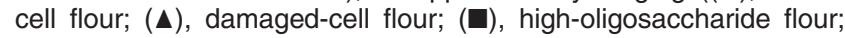
$(\square)$, low-oligosaccharide flour). For details of diets and procedures, see Table 1 and p. 380. (beans-water, 1:3, w/v), some of the RS may be partially ungelatinised starch, i.e. $\mathrm{RS}_{2}$ (Englyst et al. 1992). The starch in DCF, with its disrupted cells, was more easily degraded when exposed to the $\alpha$-amylase, and this flour contained a lower content of RS.

The LOF and HOF consisted of beans that were autoclaved in excess of water (beans-water, 1:5, w/v). Treatments at high temperature and subsequent cooling have previously been shown to result in retrograded starch, mainly retrograded amylose (Björck et al. 1987). According to the scanning electron microscopy analyses, HOF and LOF contained a relatively high proportion of intact cells, but yet displayed a lower content of RS than ICF. This finding might be explained by an increased porosity of the cell walls as a result of autoclaving, thus facilitating amylase penetration.

The higher percentage of soluble NSP in the autoclaved flours (HOF and LOF; 38) compared with the boiled flours (ICF and DCF; 26) was probably the result of the more extensive processing conditions during autoclaving (higher temperature and pressure), leading to cleavage of glycosidic linkages and disassociation of polysaccharide chains (Svanberg et al. 1995, 1997).

\section{Fermentability in the rat hindgut}

A higher fermentability of RS in the ICF diet (97) compared with the LOF + raffinose diet (86) was found in the highlevel diets, and may be explained by the presence of different forms of RS in the two diets. The present finding suggests that the microflora digests $\mathrm{RS}_{1}$ and $\mathrm{RS}_{2}$ in ICF more easily than $\mathrm{RS}_{3}$ in LOF. This conclusion is supported by the results with the low-level diets, which showed that $\mathrm{RS}$ in the ICF diet was almost quantitatively fermented (99\%). This explanation seems plausible from a physical point of view, since the $\mathrm{RS}_{1}$ type of starch may contain an important fraction of enzyme-susceptible starch, once released from the botanical cell in the hindgut. In accordance with these findings, Schulz et al. (1993) found a higher fermentability of $\mathrm{RS}_{2}(91 \%)$ than $\mathrm{RS}_{3}(64 \%)$ in rats. However, in the present study the variation in fermentability of RS within a group was relatively high. Similar results have been obtained in rats given cooked haricot beans (Phaseolus vulgaris) by Key \& Mathers (1993). A marked variation has also been reported in human subjects, indicating a high variability in the capacity of the individual colonic microflora to metabolise RS (Cummings et al. 1996).

NSP-glucans were fermented to a lower extent (37$54 \%$ ) than that reported for other heat-treated vegetables such as cooked carrots and microwaved green beans (approximately 70\%; Nyman et al. 1991; Svanberg et al. 1999). It has been suggested that RS exerts a sparing effect on NSP on fermentation in the colon, which means that bacteria prefer to ferment RS than to ferment NSP (Shetty \& Kurpad, 1986; Phillips et al. 1995; Cummings et al. 1997). In the present study all diets contained RS, which may explain the comparatively low fermentability of the NSPglucans.

The excretion of NSP-glucose in faeces was significantly higher $(P=0.037)$ with the ICF diet $(61 \%)$ than with the 
$\mathrm{LOF}+$ raffinose diet $(46 \%)$. An explanation could be that the beans in the diet LOF + raffinose had been autoclaved, which may have affected the NSP, making them more easily fermented (Björck et al. 1984; Nyman et al. 1991). The tendency to a lower faecal excretion of NSP-glucans with the HOF and LOF diets compared with the ICF and DCF diets may also be due to the fact that HOF and LOF were prepared by autoclaving the beans. The possibility that autoclaving increased the fermentability was further established by the finding that although DCF and HOF have a very similar composition with respect to indigestible carbohydrates, the HOF diet was fermented more due to the higher solubility of the NSP after autoclaving.

\section{Distribution of short-chain fatty acids in rat hindgut}

In the rat caecum, all diets yielded comparatively high percentages of butyric acid (approximately 18) compared with other substrates tested, such as pectin (7) and guar gum (11; Berggren et al. 1993). In vitro fermentation of red kidney beans has also been reported to yield high percentages of butyric acid (20-22; McBurney \& Thompson, 1987, 1989). However, it must be also taken into account that available carbohydrates (primarily starch) and protein that would normally be digested in the upper intestinal tract were available for fermentation in these studies. Fermentation of soyabean fibre in vitro led to higher proportions of butyrate than other substrates such as oat fibre, sugarbeet fibre and pea fibre (Titgemeyer et al. 1991). Relatively high percentages of butyric acid in the caecum were also observed when legumes (e.g. haricot beans 18, peas $15 \%$ ) were fed to rats (Goodlad \& Mathers, 1990; Key \& Mathers, 1995). Beans contain a complex mixture of indigestible carbohydrates, and it has been suggested that a mixture of different indigestible carbohydrates favour a higher butyrate yield (Topping et al. 1985). Further, in the present study all diets contained NDO and RS which may favour the production of butyric acid in the rat caecum. Both soyabean oligosaccharides, such as raffinose, stachyose and verbascose (Kapadia et al. 1995), and RS (Phillips et al. 1995) have been shown to yield high faecal levels of butyrate on fermentation in human subjects.

In the distal colon the ICF diet generated a significantly higher percentage of butyric acid (24) than the $\mathrm{LOF}+$ raffinose diet $(12 ; P<0 \cdot 001)$. The ICF diet contained a considerably higher amount of RS (42\% total indigestible carbohydrates) compared with the $\mathrm{LOF}+$ raffinose diet (13\% total indigestible carbohydrates). Raffinose has also been shown to yield high amounts of butyrate in the caecum of rats (Berggren et al. 1993). Raffinose, however, is readily fermented (Livesey, 1992; Berggren et al. 1993; Ferguson \& Jones, 2000), probably in the upper part of the hindgut, which might explain the low butyrate yield in the distal colon in the case of the LOF + raffinose diet.

Both diets (ICF at low- and high-levels) containing $\mathrm{RS}_{1}$ and $\mathrm{RS}_{2}$ promoted an increased butyric acid concentration in the distal colon compared with diets containing higher proportions of NDO and NSP. The increase in butyric acid concentration in the distal colon was more prominent with the diet having the highest amount of RS (i.e. ICF containing $120 \mathrm{~g}$ indigestible carbohydrates $/ \mathrm{kg}$ ). Interestingly, this diet also contained approximately the same levels of NSP and NDO as two of the diets with a low content of RS (DCF and HOF diets). The major difference between these diets was in fact the content of RS, suggesting that this form of starch contributes to the difference in butyric acid production in the distal colon. Thus, RS from the ICF seemed to be fermented mainly in the lower part of the colon. We found previously that the butyric acid concentration increased in the distal colon when a mixed diet containing high amounts of RS from potatoes and peas was fed to rats (AM Berggren, IME Björck and EMGL Nyman, unpublished results). This finding is interesting, as butyric acid has been suggested to be effective in the treatment of distal ulcerative colitis (Scheppach et al. 1992). Furthermore, the majority of colonic cancer tumours occur in the distal part of the colon in both human subjects (Bufill, 1990) and experimentally-induced rodent cancer models (Holt et al. 1996).

Further research is needed to investigate the production of butyric acid and other SCFA when various types of RS are present in combinations with other indigestible carbohydrates. In relation to colonic diseases it will be particularly interesting to study the possibility of increasing not only the butyric acid level, but also more specifically the distal yield, since diseases of the colonic epithelium most frequently occur at this site.

\section{Acknowledgements}

This work was made possible by financial support from the Swedish Foundation for Strategic Research through the LiFT Programme.

\section{References}

Åkerberg AK, Liljeberg HG, Granfeldt YE, Drews AW \& Björck IM (1998) An in vitro method, based on chewing, to predict resistant starch content in foods allows parallel determination of potentially available starch and dietary fiber. Journal of Nutrition 128, 651-660.

Asp N-G, Johansson CG, Hallmer H \& Siljeström M (1983) Rapid enzymatic assay of insoluble and soluble dietary fiber. Journal of Agricultural and Food Chemistry 31, 476-482.

Association of Official Analytical Chemists (1984) Official Methods of Analysis, 14th ed., Washington DC: AOAC.

Bach Knudsen KE \& Canibe N (1993) Changes in pig plasma lipids to dietary cholesterol, source and level of dietary fibre and caecal infusion of propionate. In COST 92 Metabolic and Physiological Aspects of Dietary Fibre in Food - Mechanisms of Action of Dietary Fibre on Lipid and Cholesterol Metabolism. Proceedings of a Workshop Held in Carry le Route-Marseille, France, 1993, pp. 123-130 [D Lairon, editor]. Luxemburg: Commission of the European Communities.

Barry IL, Hoebler C, Macfarlane GT, Macfarlane S, Mathers IC, Reed KA, Mortensen PB, Nordgaard I, Rowland IR \& Rumney CJ (1995) Estimation of the fermentability of dietary fibre in vitro: a European interlaboratory study. British Journal of Nutrition 74, 303-322.

Beaulieu KE \& McBurney MI (1992) Changes in pig serum lipids, nutrient digestibility and sterol excretion during cecal infusion of propionate. Journal of Nutrition 122, 241-245.

Berggren AM, Björck IM, Nyman EM \& Eggum BO (1993) Short- 
chain fatty acid content and $\mathrm{pH}$ in caecum of rats given various sources of carbohydrates. Journal of the Science of Food and Agriculture 63, 397-406.

Bird AR, Hayakawa T, Marsono Y, Gooden JM, Record IR, Correll RL \& Topping DL (2000) Coarse brown rice increases fecal and large bowel short-chain fatty acids and starch but lowers calcium in the large bowel of pigs. Journal of Nutrition 130, 1780-1787.

Björck I, Nyman M \& Asp N-G (1984) Extrusion cooking and dietary fiber: effects on dietary fiber content and on degradation in the rat intestinal tract. Cereal Chemistry 61, 174-179.

Björck I, Nyman M, Pedersen B, Siljeström M, Asp N-G \& Eggum BO (1987) Formation of enzyme resistant starch during autoclaving of wheat starch: studies in vitro and in vivo. Journal of Cereal Science 6, 159-172.

Björck IME \& Siljeström MA (1992) In-vivo and in-vitro digestibility of starch in autoclaved pea and potato products. Journal of the Science of Food and Agriculture 58, 541-553.

Breuer RI, Buto SK, Christ ML, Bean J, Vernia P, Paoluzi P, Di Paolo MC \& Caprilli R (1991) Rectal irrigation with short-chain fatty acids for distal ulcerative colitis. Preliminary report. Digestive Diseases and Sciences 36, 185-187.

Brighenti F, Testolin G, Canzi E, Ferrari A, Wolever TMS, Ciappellano S, Porrini M \& Simonetti P (1989) Influence of long-term feeding of different purified dietaty fibers on the volatile fatty acid (VFA) profile, $\mathrm{pH}$ and fiber-degrading activity of the cecal contents in rats. Nutrition Research 9, 761-772.

Brown I, Warhurst M, Arcot J, Playne M, Illman RJ \& Topping DL (1997) Fecal numbers of bifidobacteria are higher in pigs fed Bifidobacterium longum with a high amylose cornstarch than with a low amylose cornstarch. Journal of Nutrition 127, $1822-1827$

Bufill JA (1990) Colorectal cancer: evidence for distinct genetic categories based on proximal or distal tumor location. Annals of Internal Medicine 113, 779-788.

Campbell JM, Fahey GC Jr \& Wolf BW (1997) Selected indigestible oligosaccharides affect large bowel mass, cecal and fecal short-chain fatty acids, $\mathrm{pH}$ and microflora in rats. Journal of Nutrition 127, 130-136.

Chen WJ, Anderson JW \& Jennings D (1984) Propionate may mediate the hypocholesterolemic effects of certain soluble plant fibers in cholesterol-fed rats. Proceedings of the Society for Experimental Biology and Medicine 175, 215-218.

Cheng BO, Trimble RP, Illman RJ, Stone BA \& Topping DL (1987) Comparative effects of dietary wheat bran and its morphological components (aleurone and pericarp-seed coat) on volatile fatty acid concentrations in the rat. British Journal of Nutrition 57, 69-76.

Cummings JH, Beatty ER, Kingman SM, Bingham SA \& Englyst HN (1996) Digestion and physiological properties of resistant starch in the human large bowel. British Journal of Nutrition $\mathbf{7 5}$, $733-747$.

Cummings JH \& Englyst HN (1987) Fermentation in the human large intestine and the available substrates. American Journal of Clinical Nutrition 45, 1243-1255.

Cummings JH, Roberfroid MB, Andersson H, Barth C, FerroLuzzi A, Ghoos Y, Gibney M, Hermonsen K, James WP, Korver O, Lairon D, Pascal G \& Voragen AG (1997) A new look at dietary carbohydrate: chemistry, physiology and health. Paris Carbohydrate Group. European Journal of Clinical Nutrition 51, 417-423.

Englyst HN, Kingman SM \& Cummings JH (1992) Classification and measurement of nutritionally important starch fractions. European Journal of Clinical Nutrition 46, Suppl. 2, S33-S50.

Ferguson MJ \& Jones GP (2000) Production of short-chain fatty acids following in vitro fermentation of saccharides, saccharide esters, fructo-oligosaccharides, starches, modified starches and non-starch polysaccharides. Journal of the Science of Food and Agriculture 80, 166-170.

Goodlad JS \& Mathers JC (1990) Large bowel fermentation in rats given diets containing raw peas (Pisum sativum). British Journal of Nutrition 64, 569-587.

Granfeldt Y, Björck I, Drews A \& Tovar J (1992) An in vitro procedure based on chewing to predict metabolic response to starch in cereal and legume products. European Journal of Clinical Nutrition 46, 649-660.

Guillemot F, Colombel JF, Neut C, Verplanck N, Lecomte M, Romond C, Paris JC \& Cortot A (1991) Treatment of diversion colitis by short-chain fatty acids. Prospective and double-blind study. Diseases of the Colon and Rectum 34, 861-864.

Hague A, Elder DJ, Hicks DJ \& Paraskeva C (1995) Apoptosis in colorectal tumour cells: induction by the short chain fatty acids butyrate, propionate and acetate and by the bile salt deoxycholate. International Journal of Cancer 60, 400-406.

Hague A \& Paraskeva C (1995) The short-chain fatty acid butyrate induces apoptosis in colorectal tumour cell lines. European Journal of Cancel Prevention 4, 359-364.

Hara H, Saito Y, Nagata M, Tsuji M, Yamamoto K \& Kiriyama S (1994) Artificial fiber complexes composed of cellulose and guar gum or psyllium may be better sources of soluble fiber for rats than comparable fiber mixtures. Journal of Nutrition 124, $1238-1247$.

Holt PR, Mokuolu AO, Distler P, Liu T \& Reddy BS (1996) Regional distribution of carcinogen-induced colonic neoplasia in the rat. Nutrition and Cancer 25, 129-135.

Hoover R \& Sosulski FW (1991) Composition, structure, functionality, and chemical modification of legume starches: a review. Canadian Journal of Physiology and Pharmacology 69, 79-92.

Kapadia SA, Raimundo AH, Grimble GK, Aimer P \& Silk DB (1995) Influence of three different fiber-supplemented enteral diets on bowel function and short-chain fatty acid production. Journal of Parenteral and Enteral Nutrition 19, 63-68.

Key FB \& Mathers JC (1993) Complex carbohydrate digestion and large bowel fermentation in rats given wholemeal bread and cooked haricot beans (Phaseolus vulgaris) fed in mixed diets. British Journal of Nutrition 69, 497-509.

Key FB \& Mathers JC (1995) Digestive adaptations of rats given white bread and cooked haricot beans (Phaseolus vulgaris): large-bowel fermentation and digestion of complex carbohydrates. British Journal of Nutrition 74, 393-406.

Livesey G (1992) The energy values of dietary fibre and sugar alcohols for man. Nutrition Research Reviews 5, 61-84.

McBurney MI \& Thompson LU (1987) Effect of human faecal inoculum on in vitro fermentation variables. British Journal of Nutrition 58, 233-243.

McBurney MI \& Thompson LU (1989) Effect of human faecal donor on in vitro fermentation variables. Scandinavian Journal of Gastroenterology 24, 359-367.

Macfarlane GT \& Cummings JH (1995) Microbiological aspects of the production of short-chain fatty acids in the large bowel. In Physiological Aspects of Short Chain Fatty Acids, pp. 87-105 [JH Cummings, JL Rombeau and T Sakata, editors]. Cambridge: Cambridge University Press.

McIntyre A, Gibson PR \& Young GP (1993) Butyrate production from dietary fibre and protection against large bowel cancer in a rat model. Gut 34, 386-391.

Martin LJM, Dumon HJW \& Champ MMJ (1998) Production of short-chain fatty acids from resistant starch in a pig model. Journal of the Science of Food and Agriculture 77, 71-80.

Nygaard Johansen H, Glits $\varnothing$ V \& Bach Knudsen KE (1996) Influence of extraction solvent and temperature on the quantitative determination of oligosaccharides from plant 
materials by high-performance liquid chromatography. Journal of Agricultural and Food Chemistry 44, 1470-1474.

Nyman M, Asp NG, Cummings J \& Wiggins H (1986) Fermentation of dietary fibre in the intestinal tract: comparison between man and rat. British Journal of Nutrition 55, 487-496.

Nyman M, Schweizer TF, Pålsson K-E \& Asp N-G (1991) Effects of processing on fermentation of dietary fibre in vegetables by rats. Lebensmittel-Wissenschaft und-Technologie 24, 433-441.

Phillips J, Muir JG, Birkett A, Lu ZX, Jones GP, O'Dea K \& Young GP (1995) Effect of resistant starch on fecal bulk and fermentation-dependent events in humans. American Journal of Clinical Nutrition 62, 121-130.

Richardson AJ, Calder AG, Stewart CS \& Smith A (1989) Simultaneous determination of volatile and non-volatile acidic fermentation products of anaerobes by capillary gas chromatography. Letters in Applied Microbiology 9, 5-8.

Roediger WE (1982) Utilization of nutrients by isolated epithelial cells of the rat colon. Gastroenterology 83, 424-429.

Scheppach W, Sommer H, Kirchner T, Paganelli GM, Bartram P, Christl S, Richter F, Dusel G \& Kasper H (1992) Effect of butyrate enemas on the colonic mucosa in distal ulcerative colitis. Gastroenterology 103, 51-56.

Schulz AG, Van Amelsvoort JM \& Beynen AC (1993) Dietary native resistant starch but not retrograded resistant starch raises magnesium and calcium absorption in rats. Journal of Nutrition 123, 1724-1731.

Shetty PS \& Kurpad AV (1986) Increasing starch intake in the human diet increases fecal bulking. American Journal of Clinical Nutrition 43, 210-212.

Siavoshian S, Segain JP, Kornprobst M, Bonnet C, Cherbut C, Galmiche JP \& Blottiere HM (2000) Butyrate and trichostatin A effects on the proliferation/differentiation of human intestinal epithelial cells: induction of cyclin D3 and p21 expression. Gut 46, 507-514.

Steinhart AH, Hiruki T, Brzezinski A \& Baker JP (1996) Treatment of left-sided ulcerative colitis with butyrate enemas: a controlled trial. Alimentary Pharmacology and Therapeutics $\mathbf{1 0}$, 729-736.

Svanberg M, Gustafsson K, Suortti T \& Nyman M (1995) Molecular weight distribution, measured by HPSEC, and viscosity of water-soluble dietary fiber in carrots following different types of processing. Journal of Agriculture and Food Chemistry 43, 83-88.

Svanberg M, Sourtti T \& Nyman M (1997) Physicochemical changes in dietary fiber of green beans after repeated microwave treatments. Journal of Food Science 62, 1006-1010.

Svanberg M, Suortti T \& Nyman M (1999) Intestinal degradation of dietary fibre in green beans-effects of microwave treatments. International Journal of Food Science and Nutrition 50, 245-253.

Theander O, Åman P, Westerlund E, Anderssson R \& Pettersson D (1995) Total dietary fiber determined as neutral sugar residues, uronic acid residues, and Klason lignin (the Uppsala method): collaborative study. Journal of the Association of Official Analytical Chemists International 78, 1030-1044.

Titgemeyer EC, Bourquin LD, Fahey GC Jr \& Garleb KA (1991) Fermentability of various fiber sources by human fecal bacteria in vitro. American Journal of Clinical Nutrition 53, 1418-1424.

Todesco T, Rao AV, Bosello O \& Jenkins DJ (1991) Propionate lowers blood glucose and alters lipid metabolism in healthy subjects. American Journal of Clinical Nutrition 54, 860-865.

Topping DL, Illman RJ \& Trimble RP (1985) Volatile fatty acid concentrations in rats fed diets containing gum arabic and cellulose separately and as a mixture. Nutrition Reports International 32, 809-814.

Venter CS, Vorster HH \& Cummings JH (1990) Effects of dietary propionate on carbohydrate and lipid metabolism in healthy volunteers. American Journal of Gastroenterology $\mathbf{8 5}$, $549-553$

Vernia P, Marcheggiano A, Caprilli R, Frieri G, Corrao G, Valpiani D, Di Paolo MC, Paoluzi P \& Torsoli A (1995) Shortchain fatty acid topical treatment in distal ulcerative colitis. Alimentary Pharmacology and Therapeutics 9, 309-313.

Whitehead RH, Young GP \& Bhathal PS (1986) Effects of short chain fatty acids on a new human colon carcinoma cell line (LIM1215). Gut 27, 1457-1463.

Wolever TM, Spadafora P \& Eshuis H (1991) Interaction between colonic acetate and propionate in humans. American Journal of Clinical Nutrition 53, 681-687.

Wright RS, Anderson JW \& Bridges SR (1990) Propionate inhibits hepatocyte lipid synthesis. Proceedings of the Society for Experimental Biology and Medicine 195, 26-29. 